\title{
Farmers' Bargaining Power and Input Prices: What Can We Learn from Self-Reported Assessments? ${ }^{1}$
}

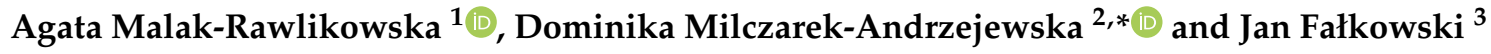 \\ 1 Faculty of Economic Sciences, Warsaw University of Life Sciences, 02-787 Warsaw, Poland; \\ agata_malak_rawlikowska@sggw.pl \\ 2 Institute of Rural and Agricultural Development, Polish Academy of Sciences, 00-330 Warsaw, Poland \\ 3 Faculty of Economic Sciences, University of Warsaw, 00-241 Warsaw, Poland; \\ jfalkowski@coin.wne.uw.edu.pl \\ * Correspondence: dmilczarek@irwirpan.waw.pl
}

Received: 30 November 2018; Accepted: 13 February 2019; Published: 18 February 2019

\begin{abstract}
One of the key challenges in improving our understanding of farmers' relations with input suppliers is that we do not have direct information about farmers' bargaining power vis-à-vis their input providers. To overcome this problem, this study used farmers' self-reported assessments of their position in the supply chain. Using unique micro-survey data from the dairy sector in Poland, we constructed a proxy of farmers' bargaining power and showed that it helps to explain discounts at which farmers buy feed from input suppliers, in addition to what is explained by the standard variables.
\end{abstract}

Keywords: farmers' self-reported bargaining power; input suppliers; price relations; dairy sector; Poland

\section{Introduction}

Given important changes in the organization of agri-food supply chains that have happened worldwide in recent years, many concerns have been expressed about the unequal distribution of power in the agri-food chain (OECD 2014). Farmers are often believed to be particularly disadvantaged in these power relations. In response to this, an extensive literature has emerged to improve our understanding of power distribution throughout the agri-food chain. As Bonanno et al. argued, the recent literature shifts from the "traditional" market power explanations to ones including concepts such as bargaining power, countervailing power, buyer power, and the role of contracts as governance tools to manage relationships in the agri-food chains (Bonanno et al. 2018). These studies typically show both problems faced by farmers as well as opportunities and solutions to improve their situation (e.g., Dries et al. 2009; Francesconi et al. 2010; Trebbin 2014).

While the existing literature has considerably improved our knowledge about the functioning of the agri-food supply chain, the evidence it provides comes with two important caveats. The first concerns the fact that most of the existing studies deal with the issue of farmers' bargaining power vis-à-vis their contractors only in an implicit way. This is because we do not usually have direct information on farmers' bargaining power. The second caveat is that the available literature focuses predominantly on farmers' linkages with downstream stages of the agri-food chain and most of the existing studies concentrate on either farmer-processor or farmer-retailer relationships. Our understanding of farmer-input supplier relations in turn is very limited (some notable exceptions include Tiessen and Funk 1993; Jarzębowski 2013; Kuijpers and Swinnen 2016). This is an important research gap given the fact that virtually almost all farmers need to purchase inputs and for many 
of them the relationship with an input supplier importantly affects both the quantity and quality of farm produce.

In this paper, we aim at addressing these issues, at least in part. Our two key contributions are as follows. The first is to complement the existing studies by providing a measure of farmers' bargaining power based on farmers' self-reported assessments of their relations within the agri-food supply chain. In doing so, we follow the organizational economics framework (see, e.g., Antras 2016), according to which the agent's position in the value chain is simultaneously shaped by his/her relations towards both downstream and upstream sectors. Accordingly, one component of our proxy of farmers' bargaining power towards input suppliers is farmers' strength vis-à-vis the downstream sectors. Using this proxy allowed us also to go beyond the standard proxies used in the literature to capture the farmers' bargaining power, i.e., the farm size, or the distance between farmers and their contractors. In effect, we could much better control for other determinants of farmers' bargaining power such as having personal contacts, the length of the relationship or negotiating skills (for the discussion about the importance of these factors, see, e.g., Dries et al. 2009; Gorton et al. 2014; Sauer et al. 2012; Swinnen 2007). To best of our knowledge, this paper is the first to empirically investigate farmers-input suppliers relations using this approach. ${ }^{2}$

The second contribution of our paper is to check to what extent our proxy can be used to inform us about the discounts that farmers receive when they pay for production inputs (for related studies, see, e.g., Collins 2007; Gorton et al. 2014; Xhoxhi et al. 2014³. As such, the paper contributes to the literature by documenting important insights on farmers-input suppliers relationship.

Our analysis used unique micro-data from interviews with 300 dairy households in Poland. The dairy sector provides the perfect setting for such analysis since potential imbalances in bargaining power have often been discussed with respect to dairy supply chain (Dries et al. 2009; Gorton et al. 2014; Dries and Swinnen 2004). Moreover, farmer-input supplier relations are quite unique there. First, in contrast to crop farmers whose contacts with input suppliers are mostly occasional and amount to buying fertilizers or pesticides, dairy farmers need to buy feed on constant basis throughout the whole year. Second, to increase their profitability, dairy farmers often decide on custom feeding, which further adds to the complexity of their relations with input suppliers. Third, feed accounts for a considerable share of total costs incurred in dairy production (in Poland, which was the focus of this study, it ranges from roughly $20 \%$ to $40 \%$ depending on the herd size; Chabuz et al. 2012; Wilczyński 2012). All this calls for improving our knowledge about dairy farmers' relations with feed suppliers. This paper is an attempt to do so.

The remainder of the paper is organized as follows. In Section 2, we provide the motivation behind our analysis. Section 3 presents our data and empirical strategy. In Section 4, we discuss the results from econometric models. Finally, Section 5 concludes.

\section{Farmers' Bargaining Power-Literature Review}

In the context of Central and Eastern Europe, i.e. the region which was the focus of this study, the issue of farmers' position in the agri-food chain has been vastly debated (see e.g., World Bank 2005; Swinnen 2007; Csaki et al. 2008). Much of this debate has been driven by specific concerns regarding small scale food producers. It has been frequently stressed that in these countries, which experienced almost fifty years of the communist dictatorship, farmers are usually poorly capitalized and thus have limited bargaining power. This is notwithstanding the fact that they are often essential to a region's economy and employment (Csaki et al. 2008). It has been also shown that the changes taking place in the agri-food supply chain, such as consolidation of downstream segments and implementation of food

2 A similar strategy was used by Fałkowski et al. (2017). Their study however analyzes farmers' relations with the processing industry and its focus is not on farmers-input suppliers relations.

3 Farmers' perception has also been extensively used in the literature studying the functioning of agricultural cooperatives (see, for example, (Osterberg and Nilsson 2009) and the citations therein). 
quality standards (Swinnen 2007; Gorton and White 2007; Dries et al. 2009), have been importantly affecting farmers' bargaining power in the chain. Further, several concerns have been expressed that these changes may have left farmers in a disadvantaged situation vis-à-vis their contractors.

That being said, the existing evidence in this respect is almost exclusively based on studies exploring farmers' relations with the downstream industry. In contrast, our understanding of the relations between input providers and farmers is very limited.

This is quite surprising, especially given the fact that there is a broad consensus that differences in input mix used by farmers can account for a large share of productivity differences across farms (Sachs 2004; FAO 2012; Wiggins and Brooks 2012). Essentially, there are two channels through which this effect may take place. On the one hand, farm inputs directly impact the quantity produced. On the other hand, they may allow producing output of a higher price-adjusted quality. Either way, access to modern inputs should allow farmers to increase their profits. It is often believed that usage of specialized farm inputs could be an important way to reduce rural poverty and contribute to food security (see, for example, FAO 2012). In this context, the fact that we know relatively little about the relations between farmers and input suppliers is something that should draw our attention. The lack of empirical evidence is especially pronounced when we turn to economies in which agriculture still accounts for a relatively large share of rural GDP or employment, such as Poland, the country which was investigated in this study. ${ }^{4}$

The focus on farmers-input suppliers relations seems to be justified also for another reason. In line with the organizational economics approach, an agent's position in the value chain will be simultaneously shaped by its relations towards both downstream and upstream sectors. Thus, improving our understanding of farmers' relations with input suppliers might be indispensable for better understanding farmers' relations with the downstream industry. To see this, recall that access of farmers to modern inputs will importantly influence the technologies they use and thus affect the quantity and quality of farm output. Consequently, it will determine the surplus that will be later distributed between farmers and processors/retailers. Access to farm inputs, and therefore relations with input suppliers, might be especially relevant in the presence of imperfect contract enforcement/contract incompleteness. This is because, under these circumstances, farmers might be particularly reluctant to invest in new technologies. The reason for this is that after incurring sunk costs of these investments they may become more vulnerable to being held up by processors/retailers. Favorable relations with input suppliers can mitigate these phenomena by decreasing the level of sunk costs. Importantly, these considerations might be particularly relevant in our context as contract incompleteness and problems with contract enforcement have been frequently identified in transition countries (Gow and Swinnen 2001; Gorton and White 2007; Swinnen 2007).

The need for improving our understanding of farmers' bargaining power towards their contractors is often recognized (OECD 2014). However, while the issue of the distribution of bargaining power in the agri-food chain is frequently debated (e.g., Dries et al. 2009; Francesconi et al. 2010; Trebbin 2014), the received literature rarely analyzes it explicitly. Often power relations are accounted for only indirectly. Those papers which try to include them in the analysis use various measures to approximate farmers' bargaining power. Probably the most common way to do so is to control for farm size or farm's location (see, e.g., Barrett 2008 or Dries et al. 2009). In addition, especially recently, the literature associates farmers' bargaining power more and more with the issue of output quality (see, e.g., Swinnen 2007). Further, it is sometimes noted that farm size and product quality may go together as smaller farms, compared to larger ones, are more likely to face credit constraints. In effect, they may

4 Polish agricultural sector is one of the largest in the EU, in terms of both the number of farms (Poland has the second largest share $(13.3 \%)$ in the total number of EU farms) or the number of people employed (third largest share (27\%) of people in rural regions employed in agriculture). The data on farm holdings refer to 2013 and come from FDPA (2016), whereas the data on agricultural employment refer to 2009 and come from the Eurostat (available at: http:/ / ec.europa.eu/eurostat/statisticsexplained/index.php/File:Employment_in_rural_regions,_2009_(\%25_share_of_total_employment)_AgriPB13.png). 
lack the necessary investment funds to upgrade quality of their output. In effect, they are likely to suffer from weaker bargaining power not only due to not being able to offer large supplies, but also because they fail to deliver products of high quality. That said, since quality issues are not easily measurable, these arguments are rarely tested with the data.

While the abovementioned aspects may definitely affect farmers' bargaining power vis-à-vis agricultural companies, focusing just on them seems to become unsatisfactory at some point. This is because such approach does not allow taking into account that farmers-contractors relationships may be quite complex and depend on many other factors in addition to those mentioned above. In fact, there is some evidence suggesting that farmers may derive their bargaining power from such factors as contract enforcement, distribution of property rights, mutual loyalty or product specific investments undertaken by the farm affecting its input-output mix (Gorton and White 2007; Dries et al. 2009; Sauer et al. 2012; Gorton et al. 2014). Other examples include farmers' personal connections or their (intrinsic) ability to negotiate prices (Do Prado and Martinelli 2016). All this suggests that farmers' bargaining power in the agri-food chain would depend not only on various tangible assets they possess, but also on the way in which they perceive strengths and weaknesses of themselves, their contractors and the environment in which they operate (Fałkowski et al. 2017). The problem though is that most of these aspects are hardly observable and thus very difficult to measure.

In this paper, we try to address these concerns and complement the existing studies by proposing an alternative way to proxy for farmers' bargaining power. More specifically, while controlling for farm size, distance between farmers and their contractors and output quality, we attempted to capture other factors that are likely to shape bargaining power in the agri-food chain with farmers' self-reported assessment of their strength. As such, our approach can be related to a growing literature showing that subjective beliefs or individual perceptions might provide important additional insights to that obtained from more objective measures (see, e.g., Leggett 2002; Marette et al. 2012; Lusk et al. 2014).

Below, we briefly present the data and the way we construct our proxy for farmers' bargaining power. We also show what empirical strategy we apply to test the relationship between this proxy and prices which farmers pay when dealing with input suppliers.

\section{Empirical Strategy}

\subsection{Data}

Our empirical study was held in June 2014 in Mazowieckie region, which is the largest milk producing region in Poland. The survey was conducted among 300 individual dairy farms through face-to-face interviews using a standardized questionnaire. The sample was designed to be representative at a regional level with respect to the farm structure according to the herd size.

In principle, the survey gathered information as of 2013/2014. However, thanks to some retrospective questions, we could also control for the main dynamics taking place at the farm between 2004 and 2013/2014. The survey data include detailed information about farmers' relations with feed suppliers. In particular, we know with how many suppliers farmers may potentially contract feed; how long they have been contracting with their current supplier; with what discount they buy feed; and whether they buy it directly from a feed producing company or through the intermediaries.

\subsection{Constructing a Proxy for Farmers' Self-Reported Bargaining Power}

When constructing our proxy for farmers' bargaining power vis-à-vis input suppliers, we tried to integrate two key points (Fałkowski et al. 2017). First, our focus was on farmers' beliefs about the extent to which they can be substituted for by their contractors. In doing so, we followed the organizational economics approach, which emphasizes that the bargaining power of the firm is increasing in substitutability of its inputs since the suppliers' threats are less effective in that case. In other words, bargaining power of the firm is the stronger the smaller losses it incurs when it decides to contract inputs outside of the specific relationship (compare with Bowles and Gintis 2008). 
This suggests that with more suppliers it should be easier for the firm to find a suitable input supplier. It should be noted that using farm size or the distance between a farm and its contractor to proxy for bargaining power can explain this aspect only imperfectly. This is because, neither of them allows controlling for the relative strength of a given farm, which depends not only on its own assets, but also on assets which are at the disposal of other farms in the neighborhood. The second point emerging from the literature, which we tried to incorporate when building our proxy for farmers' bargaining power, is that farmers' relationships with input suppliers might be affected by the relationships that farmers have with the processing industry.

Having this in mind, the survey that we used in our empirical analysis included a range of questions that aimed at capturing the two features just mentioned. To elicit farmers' subjective opinion on their position in the agri-food chain vis-à-vis input suppliers, we focused on farmers' answers to the following question: "How easy it would be for your feed supplier to find substitute for your feed purchases?". In addition, to take into account that farmers' bargaining power vis-à-vis upstream sectors might also depend on farmers' relations with downstream sectors, we analyzed farmers' responses to the question: "How easy it would be for your dairy company to find a substitute for your milk deliveries?". 5

The distribution of answers to the two questions that we used to create our proxy is presented in Figure 1. As depicted, farmers who perceive themselves as strong (weak) in their relations with input suppliers tend to also perceive themselves as strong (weak) in their relations with processors. This in turn suggests that farmers' bargaining power towards input suppliers and farmers' bargaining power towards processors can be linked to each other.

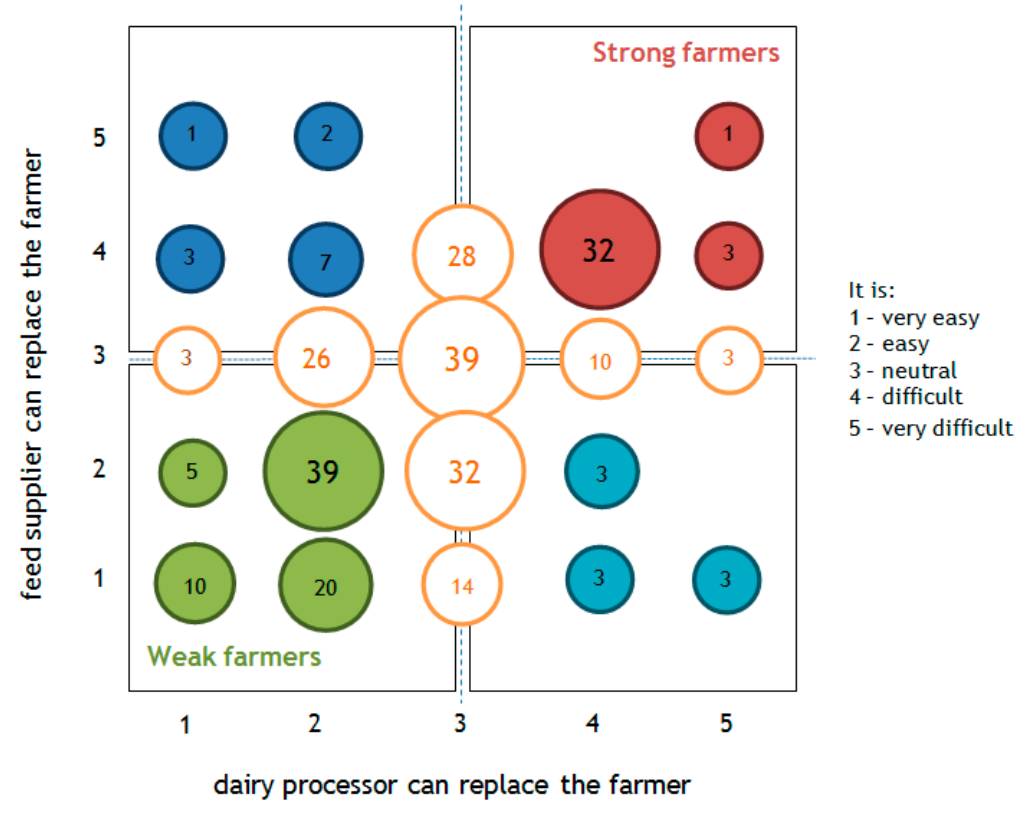

Figure 1. Farmers' subjective opinion on their bargaining power vis-à-vis dairy processors and feed suppliers (frequency of answers) Source: Authors' presentation based on survey data (Malak-Rawlikowska et al. 2017). The figure presents the number of respondents according to their answers to questions: "How easy it would be for your dairy company to find a substitute for your milk deliveries?" and "how easy it would be for your feed supplier to find substitute for your feed purchases?". The numbers on the axes from 1 to 5 refer to answers "very easy", "easy", "neutral", "difficult", and "very difficult", respectively.

5 Both were Likert scale questions. The responses, on a five-point scale, ranged from "very easy" to "very difficult". 
The strong interrelation between the two was confirmed by Mokken scale analysis and principal component analysis, which both suggested that farmers' responses to the two questions presented above can be used as an indicator for a single latent variable. ${ }^{6}$ We refer to it as farmers' bargaining power. Based on this, we defined a subsample of farmers who could be treated as having (relatively) strong bargaining power in the agri-food chain. These are 36 farmers who answered both questions "difficult" or "very difficult". ${ }^{7}$ Analogically, we defined a subsample of 74 farmers with (relatively) weak bargaining power. These are farmers who answered both questions "easy" or "very easy". 8

\subsection{Empirical Model: Explaining the Impact of Farmers' Bargaining Power on Discounts Received from Input Suppliers}

In our empirical analysis, we checked whether farmers with more bargaining power, according to the definition presented above, receive more favorable prices when dealing with their input suppliers than farmers with weaker bargaining power.

Investigating this issue was based on estimating the following model:

$$
p_{i}=\beta_{\text {strong }_{i}}+\alpha \text { size }_{i}+\vartheta \text { distance }_{i}+\mu X_{i}+\varepsilon_{i} .
$$

The dependent variable $p_{i}$ is a discount (in \%) at which a farmer $i$ buys feed. It is reported by farmers themselves and refers to the average discount which farmers receive when purchasing feed. The reference category is the price mentioned in a price list distributed to farmers by feed suppliers. The reason to focus on discounts received rather than prices paid was that prices for feed are not comparable across farms. This is because farmers often use various feed blends. ${ }^{9}$

As far as explanatory variables are concerned, our focus was on the variable strong. It is a dummy variable equal to one for farmers classified as having (relatively) strong bargaining power, as defined above, and equal to zero otherwise. ${ }^{10}$ The next variable, size, measures the size of a given farm and is defined as the (logarithm of) number of cows. ${ }^{11}$ The variable distance in turn measures the distance in kilometers between a farm and its feed supplier. Including these two variables allowed us to see whether our key variable of interest added anything to what we can get by using standard proxies for farmers' bargaining power.

Vector $X$ denotes a set of other controls which are introduced later in the text. In all estimations we included municipality fixed effects. Municipality is the lowest administrative unit in Poland and, according to the nomenclature used by Eurostat, it corresponds to LAU 2 region. Thanks to this inclusion, our findings exploited variation within farmers from the same neighborhood and thus should not be driven by (potentially large) differences between municipalities. The error term $\varepsilon_{i}$ captures all other omitted factors.

6 The results of these analyses are not shown for brevity but may be obtained from authors upon request. In the Mokken analysis, the Loevinger's scalability coefficient was equal to 0.403 and thus above the threshold of 0.3 suggested in the literature. It allowed us therefore to assume that responses to the two questions can be considered as unidimensional measure. A principal component analysis of these data in turn led to one eigenvalue larger than 1 (1.39) (Malak-Rawlikowska et al. 2017).

7 In Figure 1, these farmers are located in the upper-right corner and they are marked in red.

8 In Figure 1, these are farmers located in the bottom-left corner and they are marked in green.

9 Looking at the role of discounts in the context of farm inputs is not new and can be found also elsewhere. See, e.g., Duflo et al. (2011) who showed that small discounts on inputs costs (in their case fertilizers) may have an important effect on increasing the usage of inputs.

10 To test the robustness of our results, we also applied an alternative strategy to define this variable. More specifically, we limited our sample to strong and weak farmers only, i.e. we excluded from our analysis all farmers with a moderate bargaining power. In that case, our key variable of interest was defined as equal to one if a farmer is relatively strong and zero if farmer is relatively weak. Using this approach, the coefficient on the variable measuring farmers' bargaining power was larger in magnitude. It was not always as precisely estimated (due to smaller sample size) but remained statistically significant at least at $10 \%$ level. These results are not shown for brevity but can be obtained from authors upon request (Malak-Rawlikowska et al. 2017).

11 Our results remain qualitatively the same if instead we use milk quota in $\mathrm{kg}$. 
The specification presented above was estimated using tobit model. This choice was motivated by the fact that our dependent variable is censored from below and takes many zeros (for those farmers who report discount equal to zero we do not know whether the price paid is not higher than what is normally charged for a given type of feed). ${ }^{12}$ For this kind of data, simple OLS method provides inconsistent estimates (see, e.g., Long 1997). In the paper, all standard errors are robust, clustered at the feed supplier level to allow for an arbitrary variance-covariance matrix capturing potential serial correlation in the residual term.

\section{Results}

\subsection{Descriptive Analysis}

We started with analyzing farmers' overall assessment of their relations with feed suppliers. To do so, we investigated responses to the question "How do you assess your relationship with your feed supplier", which aimed at capturing the level of farmers' satisfaction with their current contractors. A great majority of our respondents (94\%) perceives the relationship with feed supplier as either good or very good, and never as bad or very bad. We also found that farmers have on average a long and stable cooperation with feed suppliers (6.5 years). This was further confirmed by the fact that within the last 10 years the average number of changes of feed suppliers is equal to 1.1. Further, over the last 10 years, roughly $45 \%$ of farmers have not changed their feed supplier even once. Interestingly, this stable relationship takes place notwithstanding the fact that over $90 \%$ of farmers in our sample do not have a written contract with feed suppliers. Moreover, a great majority of our respondents $(94 \%)$ believes changing feed suppliers would be relatively easy for them.

There are two main channels through which the surveyed farmers buy feed: a direct purchase from a feed producing company and a purchase from an intermediary operating in the animal feed sector (e.g., local shops, which offer different feeds). Overall, $45 \%$ of our respondents purchase feed directly from the feed producing company and $49 \%$ source feed from the feed intermediaries. Farmers can also buy feed through the dairy processing company, but only $4 \%$ of our respondents used this source of feed supplies.

Our data also provide interesting insights on price negotiations between farmers and feed suppliers. Fifty-nine percent of farmers answered that they negotiate prices of feed. This share is much higher among farmers who purchase feed from producers (71.7\%) than among farmers who buy from intermediaries (47.3\%). The frequency of negotiations is positively correlated with the farm size and the discount level (in both supply channels). This suggests that larger farms more often negotiate prices and that the negotiations may indeed produce the desired effects in the form of more favorable prices for farmers.

Further insights on farmer-feed suppliers relationships are provided in Table 1. The table shows descriptive statistics for our entire sample (Column (1)) and also for subsamples created according to farmers' perception on how confident they feel about their bargaining power in the agri-food chain (Columns (2)-(4)).

First, farmers who perceive themselves as relatively strong in the agri-food chain (Column (2)) have significantly larger herds and farms then weak farmers (Column (3)). It is important to note that this difference is persistent over time, as we observed it both for 2013 and 2004. Further, strong farmers receive, on average, significantly higher milk price than the weak farmers. This could be determined either by a larger quantities of milk delivered or by some factors affecting farmers' bargaining power. The quality of milk however does not seem to be the driving factor as we found no statistically

12 As an alternative, we also tried to estimate the main equation of interest using zero inflated model. The results obtained using this method are qualitatively the same as the one using tobit approach. They are not reported for brevity but may be obtained from authors upon request. 
significant difference between strong and weak farmers as regards milk quality parameters (fat and protein content).

Table 1. Selected descriptive statistics for the variables used in the analysis (mean, standard deviation).

\begin{tabular}{|c|c|c|c|c|}
\hline Characteristics & $\begin{array}{l}(1) \\
\text { Total Sample } \\
(n=300)\end{array}$ & $\begin{array}{l}(2) \\
\text { Strong Farmers } \\
(\mathrm{n}=36)\end{array}$ & $\begin{array}{l}(3) \\
\text { Weak Farmers } \\
(\mathrm{n}=74)\end{array}$ & $\begin{array}{l}(4) \\
\text { Other Farmers } \\
(n=190)\end{array}$ \\
\hline Herd size 2013 (no. of cows) ${ }^{* *}$ & $\begin{array}{c}26.9 \\
(20.6)\end{array}$ & $\begin{array}{c}31.5 \\
(20.9)\end{array}$ & $\begin{array}{c}24.7 \\
(21.3)\end{array}$ & $\begin{array}{c}27.0 \\
(20.2)\end{array}$ \\
\hline Land owned 2013 ** & $\begin{array}{c}29.1 \\
(18.9)\end{array}$ & $\begin{array}{c}33.4 \\
(17.2)\end{array}$ & $\begin{array}{c}25.3 \\
(14.1)\end{array}$ & $\begin{array}{c}29.7 \\
(20.7)\end{array}$ \\
\hline Herd size 2004 (no. of cows) ${ }^{* *}$ & $\begin{array}{c}17.6 \\
(13.0)\end{array}$ & $\begin{array}{l}17.9 \\
(8.4)\end{array}$ & $\begin{array}{c}15.4 \\
(10.5)\end{array}$ & $\begin{array}{c}18.3 \\
(14.6)\end{array}$ \\
\hline Land owned $2004^{* *}$ & $\begin{array}{c}24.1 \\
(14.3)\end{array}$ & $\begin{array}{c}25.1 \\
(11.4)\end{array}$ & $\begin{array}{c}21.2 \\
(10.0)\end{array}$ & $\begin{array}{c}25.0 \\
(16.0)\end{array}$ \\
\hline $\begin{array}{l}\text { Discount from feed supplier (as a } \% \text { of the } \\
\text { initial price offered) }\end{array}$ & $\begin{array}{c}3.1 \\
(3.6)\end{array}$ & $\begin{array}{c}3.1 \\
(3.6)\end{array}$ & $\begin{array}{c}2.8 \\
(3.8)\end{array}$ & $\begin{array}{l}3.3 \\
(3.7)\end{array}$ \\
\hline $\begin{array}{l}\text { Share of farmers buying feed directly from } \\
\text { feed producer* }\end{array}$ & $42 \%$ & $63 \%$ & $42 \%$ & $38 \%$ \\
\hline $\begin{array}{l}\text { Share of farmers considering change of feed } \\
\text { supplier (yes or from time to time) }\end{array}$ & $36 \%$ & $72 \%$ & $36 \%$ & $29 \%$ \\
\hline $\begin{array}{l}\text { Do you negotiate prices with feed supplier } \\
\qquad(\% \text { of yes) }\end{array}$ & $59 \%$ & $69 \%$ & $48 \%$ & $62 \%$ \\
\hline $\begin{array}{l}\text { Frequency of feed purchases (share of } \\
\text { farmers buying once a week and more } \\
\text { often) }\end{array}$ & $\begin{array}{l}17 \% \\
(0.9)\end{array}$ & $\begin{array}{l}17 \% \\
(0.8)\end{array}$ & $\begin{array}{l}27 \% \\
(1.0)\end{array}$ & $\begin{array}{l}15 \% \\
(0.9)\end{array}$ \\
\hline Age (years) & $\begin{array}{c}44.3 \\
(10.3)\end{array}$ & $\begin{array}{c}44.5 \\
(11.5)\end{array}$ & $\begin{array}{l}45.7 \\
(9.9)\end{array}$ & $\begin{array}{c}43.7 \\
(10.2)\end{array}$ \\
\hline $\begin{array}{l}\text { Is it possible to get better conditions by } \\
\text { group negotiations with feed supplier ** (\% } \\
\text { of yes) }\end{array}$ & $63 \%$ & $83 \%$ & $57 \%$ & $61 \%$ \\
\hline $\begin{array}{l}\text { a "Strong" farmers (see Figure } 1 \text { ) hav } \\
\text { farmers have weak bargaining pow } \\
\text { remaining apart from this two extrem } \\
\text { between strong and weak farmers. S } \\
\text { on the survey sample (Malak-Rawlik }\end{array}$ & $\begin{array}{l}\text { ong bargainin } \\
\text { s. feed suppl } \\
* * p<0.01,{ }^{* *} p \\
\text { ard deviation } \\
\text { ka et al. 2017) }\end{array}$ & $\begin{array}{l}\text { ver vs. both fee } \\
\text { d dairy proces } \\
5, * p<0.1 \text { signi } \\
\text { given in bracke }\end{array}$ & $\begin{array}{l}\text { plier and dairy } \\
\text { ind "other" far } \\
\text { e levels calcula } \\
\text { urce: Authors" }\end{array}$ & $\begin{array}{l}\text { cessor; "weak" } \\
\text { s are all those } \\
\text { or a difference } \\
\text { ulations based }\end{array}$ \\
\hline
\end{tabular}

Importantly given our focus, $54 \%$ of farmers report receiving some discount from input suppliers. The mean discount is $3.1 \%$, the median is $2 \%$, and the largest discount is $18 \%$. Interestingly, sample averages do not allow us to argue that the two groups under study differ in terms of the discount obtained from feed supplier. Although the discount for strong farmers seems to be higher than for the weak ones, the difference between the two is not statistically significant. According to the opinion of farmers, the discount mainly depends on the size of feed purchases (60\% of farmers declared this) and being a loyal client (36\% of respondents mentioned this answer). This is confirmed by the fact that discount level and size of the dairy herd are positively correlated. The relationship in question however, although highly statistically significant, is not that strong (the correlation coefficient is equal to $0.31 ; p<0.01$ ).

About $63 \%$ of farmers having relatively strong position is buying feed directly from the feed producer instead of intermediates. This share is larger than that observed for farmers with a relatively weaker bargaining position (42\%) and this difference is statistically significant. In addition, compared to farmers with weak position, farmers more confident about their bargaining power more often consider changing the current feed supplier, tend to have significantly larger choice of potential contractors and more often negotiate prices (Table 1).

The two groups do not differ in terms of age, sex or farming experience. However, the differences can be observed between farmers with strong and weak position in terms of their belief about the effectiveness of group negotiations. Weak farmers, more often than strong farmers, agree with 
the opinion that collective action may be helpful in getting more favorable conditions from feed suppliers. This suggests then that farmers' bargaining power may be determined also by their attitude to cooperation.

Based on the analysis presented above, we can assume that farmers from our sample are not in the disadvantageous position versus feed suppliers as they can negotiate prices and receive discounts, even though they do not have a written contract with suppliers. We next tried to see whether the bargaining power that farmers have in these relationships translates into higher discounts which they can receive when buying feed.

\subsection{Impact of Farmers' Bargaining Power on Prices of Feed}

With the use of econometric modeling, we investigated the relationship between our proxy for farmers' bargaining power and discounts on prices of feed. While doing so, we controlled for variables describing farms' characteristics, which are commonly assumed to determine farmers' negotiating position such as farms' size or location (Sauer et al. 2012; Xhoxhi et al. 2014). We also controlled for other factors that may correlate with farmers' bargaining power as suggested by the statistics reported in Table 1.

Table 2 presents our results. Column (1) reports the first specification which includes only our key variable of interest and municipality fixed effects. We found a positive coefficient that is statistically significant at $10 \%$. It implies that feeling strong within the agri-food chain results in a discount larger by $1.89 \%$. This is a considerable effect given that the average discount in our sample is $3.13 \%$ (with standard deviation equal to 0.037 ).

Table 2. Farmers' subjective bargaining power and discount obtained when buying feed.

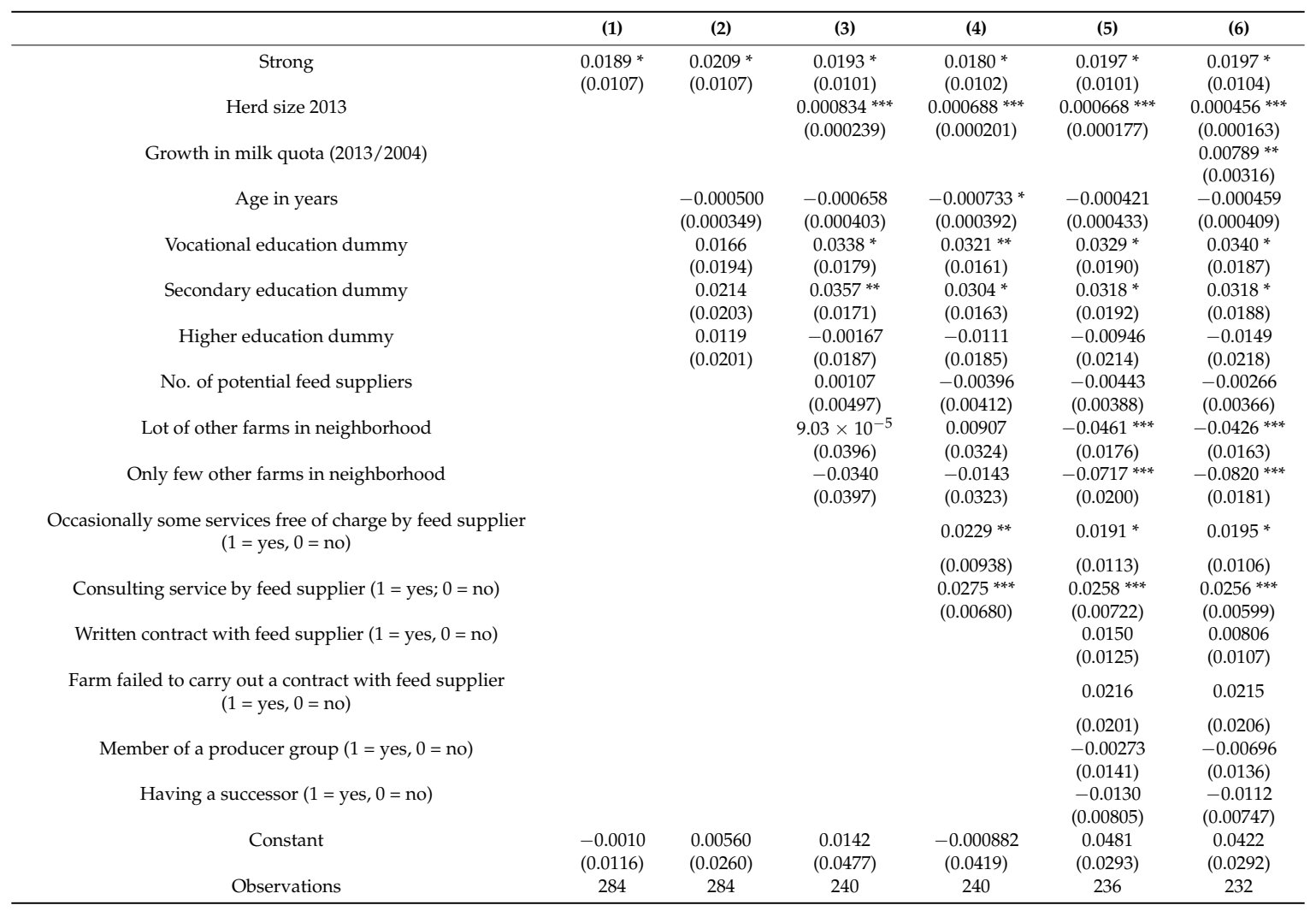

*** $p<0.01,{ }^{* *} p<0.05,{ }^{*} p<0.1$. Robust standard errors, clustered at feed supplying company level, in parentheses. All regressions include municipalities fixed effect. Source: Authors' calculations based on the survey sample (Malak-Rawlikowska et al. 2017). 
As shown in Column (2), we added variables measuring farmer's age and education level. ${ }^{13}$ This was done to capture farmer's human capital, which can affect both the way the farm is managed and the relationships with input suppliers. Including these variables had almost no impact on the effect of our key variable of interest.

As shown in Column (3) we tested the robustness of our results to some other covariates: herd size and three variables describing the environment in which a given farm is operating (the number of feed suppliers that a given farmer could potentially approach and two dummy variables indicating whether in the farmer's neighborhood there are also other farms). This way we controlled for the fact that feed suppliers may favor clients clustered geographically to minimize transport costs. As expected, the coefficient by the variable measuring herd size is positive and highly significant, while the other covariates are not statistically significant. Most importantly, however, our key variable of interest instead remains significant at $10 \%$ and of similar magnitude as before.

As shown in Column (4), we extended our analysis by incorporating two additional variables to account for the fact that feed suppliers could favor and preselect farmers for the future cooperation. For that purpose, we included a dummy variable distinguishing farms that from time to time obtain some services from feed suppliers free of charge. We also added a dummy variable distinguishing farms that obtain regular consulting services regarding feeding their herd. Both variables entered our regressions with a positive sign and are statistically significant, which support the above-mentioned hypothesis. It is important to note that the effect of our key variable of interest remains as before, notwithstanding the fact that age and education variables become now statistically significant.

As shown in Column (5), we included three additional variables: having written contract with feed supplier, experiencing problems with carrying out the contract with feed supplier, being a member of a producer group or having a successor to take over a farm. None of these variables is statistically significant. However, our previous results remain robust in this specification.

Finally, Column (6) presents results of the specification in which we checked whether anything changes if, in addition to herd size, we also included a variable measuring the growth of milk quota over the period 2004-2014. While the coefficient on this variable is positive and statistically significant, our main variable of interest remains to be significant at $10 \%$ and of similar magnitude as before. ${ }^{14}$

Overall, therefore, we foud a persistent positive correlation between farmers' bargaining power in the agri-food chain and the discount at which they buy feed from their suppliers. This is noteworthy, as this effect holds in many specifications in which we controlled for a range of factors that are likely to shape farmers' bargaining power. Our proxy therefore seems to provide additional insights to that coming from using standard variables describing farmers' bargaining power in the agri-food chain. It needs to be clearly noted, however, that our findings are based on cross-sectional data and therefore they might be potentially biased due to unobserved heterogeneity. This caveat needs to be kept in mind while interpreting our results.

\section{Conclusions}

Most of the existing studies on a situation of farmers in the modern agri-food supply chains concentrate on either farmer-processor or farmer-retailer relations. In this study, we aimed to adopt a different focus and to improve our understanding of the backward vertical spillovers between the farmers and input suppliers.

For that purpose, we analyzed data from 300 dairy farms in Poland. While caution needs to be exercised in making claims about external validity, we believe that what we uncovered here might

13 There are three dummy variables capturing subsequent levels of farmer's education and the reference category is elementary school.

14 It might be worth noting that the latter model is the one for which the Akaike information criterion has the smallest value and therefore it might be considered to be better than the other models presented. 
be of broader interest. This is because the restructuring that has been taking place in the Polish dairy sector resembles, in many aspects, the changes observed elsewhere.

Our contribution is twofold. First, we documented farmer-input supplier relations and showed that farmers from our sample do not seem to be in the disadvantageous position versus feed suppliers. They can negotiate prices, have alternative contractors and receive discounts on prices of feed. Further, a great majority of farmers perceive their relationship with feed suppliers as either good or very good. This is consistent with the fact that we found that farmers have, on average, a long and stable cooperation with feed providers. Importantly, this is despite the fact that over $90 \%$ of them do not have any written contract with their input suppliers.

Second, according to the results of our study, farmers' self-reported bargaining power is a good predictor of the discounts they obtain when buying feed. Especially, farmers who perceive themselves as being "strong" in the agri-food chain receive higher discount from feed suppliers than farmers who believe they have weaker position. It is important to note that these results remain robust when we control for a number of other potential determinants of the discounts. Our findings suggest, therefore, that taking into account farmers' subjective assessment of their bargaining position in the agri-food chain may provide additional insights into farmers' bargaining power understanding. With this approach, we go beyond standard variables highlighted in the literature, such as farm size or farm's geographical location. Testing these results to other methodological approaches and/or in other geographical contexts seems to be a fruitful line for future research.

Author Contributions: Conceptualization, J.F., A.M.-R. and D.M.-A.; methodology, J.F., A.M.-R. and D.M.-A..; formal analysis, J.F., A.M.-R. and D.M.-A.; investigation, J.F., A.M.-R. and D.M.-A.; resources, J.F., A.M.-R. and D.M.-A.; writing —original draft preparation, J.F., A.M.-R. and D.M.-A.; writing-review and editing, J.F., A.M.-R. and D.M.-A.; funding acquisition, J.F.

Funding: The research was conducted within the Seventh EU Framework Programme project titled COMPETE (International comparisons of product supply chains in the agri-food sectors: determinants of their competitiveness and performance on EU and international markets) co-financed by the European Commission and the Polish Ministry of Science and Higher Education.

Conflicts of Interest: The authors declare no conflict of interest.

\section{References}

Antras, Pol. 2016. Global Production. Firms, Contracts and Trade Structure. Princeton: Princeton University Press.

Barrett, Christopher B. 2008. Smallholder market participation: Concepts and evidence from eastern and southern Africa. Food Policy 33: 299-317. [CrossRef]

Bonanno, Alessandro, Carlo Russo, and Luisa Menapace. 2018. Market Power and Bargaining in Agrifood Markets: A Review of Emerging Topics and Tools. Agribusiness 34: 6-23. [CrossRef]

Bowles, Samuel, and Herbert Gintis. 2008. Power. In The New Palgrave Dictionary of Economics. Edited by Steven N. Durlauf and Laurent E. Blume. Basingstoke and New York: Palgrave Macmillan.

Chabuz, Witold, Zygmunt Litwinczuk, Waldemar Teter, Piotr Stanek, and Aneta Brodziak. 2012. Pokrycie potrzeb pokarmowych i koszty produkcji mleka w gospodarstwach o różnych systemach żywienia krów. Roczniki Naukowe Polskiego Towarzystwa Zootechnicznego 8: 27-39.

Collins, Alan. 2007. Retail control of manufacturers' product-related activities: Evidence from the Irish food manufacturing industry. Journal of Food Products Marketing 13: 1-18. [CrossRef]

Csaki, Csaba, Csaba Forgacs, Dominika Milczarek-Andrzejewska, and Jerzy Wilkin. 2008. Restructuring Market Relations in Food and Agriculture in Central and Eastern Europe: Impacts upon Small Farmers. Budapest: Agroinform.

Dries, Liesbeth, Etleva Germenij, Nivelin Noev, and Johan Swinnen. 2009. Farmers, vertical coordination, and the restructuring of dairy supply chains in Central and Eastern Europe. World Development 37: 1742-58. [CrossRef]

Dries, Liesbeth, and Johan Swinnen. 2004. Foreign Direct Investments, Vertical Integration and Local Suppliers: Evidence from the Polish Dairy Sector. World Development 32: 1525-44. [CrossRef] 
Duflo, Esther, Michael Kremer, and Jonathan Robinson. 2011. Nudging Farmers to Use Fertilizers: Theory and Experimental Evidence from Kenya. American Economic Review 101: 2350-90. [CrossRef]

FAO. 2012. Fertilizers Subsidies in Sub-Saharan Africa. ESA Working Paper No. 12-04. Rome: FAO.

Fałkowski, Jan, Agata Malak-Rawlikowska, and Dominika Milczarek-Andrzejewska. 2017. Farmers' self-reported bargaining power and price heterogeneity: Evidence from the dairy supply chain. British Food Journal 119: 1672-86. [CrossRef]

FDPA. 2016. Polska Wieś 2016. Raport o Stanie Wsi. Warsaw: FDPA.

Francesconi, Gian Nicola, Nico Heerink, and Marijke D’Haese. 2010. Evolution and challenges of dairy supply chains: Evidence from supermarkets, industries and consumers in Ethiopia. Food Policy 35: 60-68. [CrossRef]

Gorton, Matthew, Robert Angell, Liesbeth Dries, Vardan Urutyan, Elizabeth Jackson, and John White. 2014. Power, buyer trustworthiness and supplier performance: Evidence from the Armenian dairy sector. Industrial Marketing Management 50: 69-77. [CrossRef]

Gorton, Matthew, and John White. 2007. Transformation and contracting in the supply chains of the former Soviet Union. In Global Supply Chains Standards and The Poor: How the Globalisation of Food System and the Standards Affects Rural Development and Poverty. Edited by Johan F. M. Swinnen. Wallingford: CABI, pp. 175-87.

Gow, Hamish R., and Johan Swinnen. 2001. Private enforcement capital and contract enforcement in transitional economies. American Journal of Agricultural Economics 83: 686-90. [CrossRef]

Jarzębowski, Sebastian. 2013. Integracja Łańcucha Dostaw Jako Element Kształtowania Efektywności Sektora Przetwórstwa Rolno-Spożywczego. Treatises and Monographs, No 422. Warszawa: Wydawnictwo SGGW.

Kuijpers, Rob, and Johan Swinnen. 2016. Value Chains and Technology Transfer to Agriculture in Developing and Emerging Economies. Paper presented at 2016 Allied Social Sciences Association (ASSA) Annual Meeting, San Francisco, CA, USA, January 3-5.

Leggett, Christopher G. 2002. Environmental valuation with imperfect information: The case of the random utility model. Environmental and Resource Economics 23: 343-55. [CrossRef]

Long, John Scott. 1997. Regression Models for Categorical and Limited Dependent Variables. Advanced Quantitative Techniques in the Social Science. No 7. Thousand Oaks: Sage Publications.

Lusk, Jayson L., Ted Schroeder, and Glynn Tonsor. 2014. Distinguishing beliefs from preferences in food choice. European Review of Agricultural Economics 41: 627-55. [CrossRef]

Malak-Rawlikowska, Agata, Dominika Milczarek-Andrzejewska, and Jan Fałkowski. 2017. Quantitative assessment of impact of the farmers' self-reported bargaining power on price relations with input suppliers. Paper presented at the XV EAAE Congress "Towards Sustainable Agri-food Systems: Balancing between Markets and Society", Parma, Italy, August 28-September 1.

Marette, Stéphan, Brian E. Roe, and Mario Teisl. 2012. The welfare impact of food pathogen vaccines. Food Policy 3: 86-93. [CrossRef]

OECD. 2014. Competition Issues in the Food Chain Industry. DAF/COMP(2014)16. Paris: OECD.

Osterberg, Peter, and Jerker Nilsson. 2009. Members' Perception of their Participation in the Governance of Cooperatives: The Key to Trust and Commitment in Agricultural Cooperatives. Agribusiness 25: 181-97. [CrossRef]

Do Prado, Lucas Sciencia, and Dante Pinheiro Martinelli. 2016. Analysis of negotiation strategies between buyers and sellers: An applied study on crop protection products distribution. RAUSP Management Journal 53: 225-40. [CrossRef]

Sachs, Jeffrey. 2004. The Case for Fertilizer Subsidies for Subsistence Farmers. Working Paper. New York: The Earth Institute at Columbia University.

Sauer, Johannes, Matthew Gorton, and John White. 2012. Marketing, cooperatives and price heterogeneity: Evidence from the CIS dairy sector. Agricultural Economics 43: 165-77. [CrossRef]

Swinnen, Johan F. M., ed. 2007. The dynamics of vertical coordination in agri-food supply chains in transition countries. In Global Supply Chains, Standards and the Poor. Oxon: CABI, pp. 42-58.

Tiessen, James H., and Thomas F. Funk. 1993. Farmer bargaining when purchasing machinery and fertilizer: A study in commercial negotiation. Agribusiness 9: 129-42. [CrossRef]

Trebbin, Anika. 2014. Linking small farmers to modern retail through producer organizations—Experiences with producer companies in India. Food Policy 45: 35-44. [CrossRef] 
Xhoxhi, Orjon, Søren Marcus Pedersen, Kim Martin Lind, and Attila Yazar. 2014. The Determinants of Intermediaries' Power over Farmers' Margin-Related Activities: Evidence from Adana, Turkey. World Development 64: 815-27. [CrossRef]

Wiggins, Steve, and Jonathan Brooks. 2012. The use of input subsidies in low-income countries. In Agricultural Policies for Policy Reduction. Paris: OECD Publishing.

Wilczyński, Artur. 2012. Wielkość stada krów a koszty i dochodowość w produkcji mleka. Roczniki Nauk Rolniczych, Seria G 99: 69-80.

World Bank. 2005. The Dynamics of Vertical Co-Ordination in Agro-Food Chains in Europe and Central Asia. Washington: The World Bank. article distributed under the terms and conditions of the Creative Commons Attribution (CC BY) license (http:/ / creativecommons.org/licenses/by/4.0/). 